I UC STUDI ES

ISSN 1813-7733

Vol. - 4, December 2007

Published in April 2008 (p 49-58)

\title{
The Lyrical Strain in Victorian Poetry
}

\begin{abstract}
Md. Nazmul Huda ${ }^{*}$
Abstract: This article is an attempt to explore the lyrical strain in Victorian Poetry ${ }^{1}$. It has been demonstrated that lyrical strain is the combination of subjectivity and melody. Some particular lyric poems of Victorian period have been studied with the help of the views and comments of some critics so that better comprehension of the lyrics as well as the poets may be carried out. Lyrical allusions and references have been drawn from the poems of Tennyson, Arnold and Rossetti to present how the sources of their lyricism vary from one another. In presenting the lyrical features of their poems, the critical method followed is based upon comparison and contrast. Since literature is deemed to be the reflection of life, this study may help the readers understand sentiments and emotions of men and women of that particular period.
\end{abstract}

A lyric poem covers certain attributes like subjectivity, imagination, melody and emotion. In other words, it signifies a verse "that expresses intense personal emotion in a manner suggestive of a song." (Goetz, 1986, p. 593) In the modern sense, any poetry that sets out to express the thoughts and feelings of the poet is called lyric poetry. However, "although the lyric is uttered in the first person, the ' $\mathrm{I}$ ' in the poem need not be the poet who wrote it." (Abrams, 1993, p. 108) A lyrical strain is the coalescence of personal feelings and melody.

The lyrical strain is evident in Victorian lyric poetry consisting of songs, ballads, elegies and other kinds of poems. In these lyrics, the poets give vent to personal thoughts and feelings. Of course, sometimes, they introduce a speaker who pours out their personal emotions. The subjective sentiments are often expressed through melodious language, alliteration, assonance, allocation, onomatopoeia, and refrain. Some examples from the poems of Tennyson, Arnold and

${ }^{*}$ Lecturer, Department of English Language and Literature, IIUC 
Rossetti will clarify how the lyrical strain is made felt in Victorian poetry.

As for Tennyson, many of his poems such as In Memoriam (1850), "Mariana” (1830) and "Break, Break, Break" (1842) are full of lyrical strains. He plays out divergent emotions; and in most cases, he speaks of his own grief, doubt and faith, while sometimes he presents a lyrical speaker expressing his or her personal feelings. Tennyson's music in his lyrics gives an impression that he was born with a gift for music. When he was a small child he exclaimed on stormy nights: "I hear a voice that's speaking in the wind." (Burton, 1954, p. 11) And even a hurried reading of his poems will reveal a manifestative ability to record every kind of noise in nature, "from the roaring of the North Sea breakers to the murmur of the bees in the Somersbly flowers."(Burton, 1954, p. 11) Nonetheless, the most enchanting sound was that of the human speech. Enthralled by the beauty of the spoken word, he appears to have mastered the verbal sound, and not to read his poetry aloud is almost as self-denial as to read a "sonata of Beethoven without playing it.”(Burton, 1954, p. 11) His use of alliteration and refrain and onomatopoeia all show him to be a master craftsman in the technique of his art. This perfection does not stem from “a studied, but an unconscious one," (Burton, 1954, p. 11) as Hester Burton writes: "He said to a friend in his youth alliteration came so naturally to him that when he wrote his poetry down he carefully weeded it out of his verse, because he thought his audience might laugh at the too frequent repetition of his consonant sounds."(Burton, 1954, p. 11) Likewise, the melodious effects his vowel sounds produce and the wonderful appropriateness of many of his metres do not seem to be the aftermath of conscious and laborious search, but of an immediate and inspired discovery. Some of Tennyson's poems already mentioned above will be typical of illustrating the mode of lyrical strain in his poetry.

Tennyson's In Memoriam (1850), a characteristic poem of diverse personal feelings, consists of a hundred and thirty-one lyrics, 'short swallow-flights of song,' composed at intervals during seventeen years. [Tennyson frequently raises the question of poetic form and poetic purpose in the poem, characterizing the verses as "short swallowflights of song, that dip/their wings in tears, and skim away" (In Memoriam, 14-15 sec. 48, p. 1103)] This poem, viewed by many critics as one of Tennyson's greatest, is an elegy on the death of his 
friend, Arthur Henry Hallam, and it records how the author overcame his profound personal grief. He looks upon Hallam's death as if it were the death of the world, and his personal sorrow as a universal one. The affirmation which he reaches after going through his chagrin and misgiving is his trust in a reality where exists a god of love and individual immortality. In the beginning, the early phases of grief are touched upon, which express moods of stunned and bewildered sorrow:

He is not here: but far away

The noise of the life begins again,

And ghastly through the drizzling rain

On the bold street breaks the blank day.

(In Memoriam, 9-12, p. 1090)

Gradually the personal pain merges itself into anxious speculation concerning the mystery of death and the hope of immortality:

I stretch lame hands of faith, and grope,

And gather dust and chaff, and call

To what I feel is Lord of all,

And faintly thrust the larger hope. (In Memoriam, 17-20, p. 1104)

Through states of doubt, despair, and anguished question, the poem slowly mounts to a firm though saddened faith and ends in a full hymnal music breathing hope and fortitude of the heart:

O living will that shallot endure,

When all that seems shall suffer shocks,

Rise from the spiritual rock,

Flow through our deeds and make them pure. (In Memoriam, 1-4, p. 1105)

Nevertheless, this poem records Tennyson's doubt very dominantly, as M. H. Abrams mentions that

"The death of Hallam, the religious uncertainties that he had himself experienced, together with his own extensive study of writings by geologists, astronomers, and biologists, led 
him to confront many of the religious issues." (Abrams, 1993, p. 1055)

His doubt about the soul springs out of the scientific discovery of fossils which show the extinction of innumerable species of the past. He articulates the following typical lines:

So careful of the type? but no

From scarped cliff and quarried stone

She cries, 'A thousand types are gone:

I care for nothing, all shall go.'(In Memoriam, 1-4, p. 1131)

Therefore, we see his doubt has firm grounds. In this regard, T. S. Eliot rightly remarks: "the poem, he wrote, is remarkable not because of the quality of its faith but because of the quality of its doubt." (Abrams, 1993, p. 1055) The aforesaid lines from In Memoriam (1850) not only express personal feelings, but also produce tremendous music. To enhance this musical quality, alliteration, assonance and a particular rhyme scheme are employed. In the alliteration made of ' $g$ ' (begin, again, ghastly), 'r' (through, drizzling, rain) and 'b' (bold, break, blank) sounds creates melodious effect and so does the recurrence of 'l', 's' and ' $c$ ' sounds in the other lines mentioned. Assonantal effect is slim; still the last two lines show it, as the vowel sound of 'o' (from, rock, flow, through) recurs. Again the rhyme scheme, here, is abba that evokes the symphony of a song. Hence, we recognize In Memoriam (1850) as a Victorian poem displaying lyrical strain to the fullest extent.

"Mariana"(1830) is another song-like poem evincing lyrical traits. In this lyric, Tennyson creates a speaker, Mariana, who laments for her unrequited love and thereby gives vent to her despair and desolation:

Then said she 'I am very dreary,

He will not come,' she said;

She wept 'I am aweary, aweary ,

Oh God that I were dead.’ (“Mariana”, 81-84, p. 1058)

In moments of her great anguish the petty, unimportant details of her surroundings are so impressive that her mind and grief become one. Hester Burton remarks about the melancholic atmosphere that is harmonized with her dull mood: 
"The shadow of the poplar tree, the doors creaking on their hinges, the sparrows chirruping on the roof, and all the other sad furniture of this mouldering moated grange are each in turn but another pang in Mariana's desolation.”(Burton, 1954, p. 42)

In fact, Mariana's mental agony is further aggravated by the environment she lives in.

Mariana awaits the arrival of her lover; days and nights elapse, but he does not come to her at all. This turns her life bleak and barren. The desolation in Mariana's life reminds a reader of

“The long postponement of Tennyson's marriage to Emily Sellwood with whom he had fallen in love in 1836 but could not marry, because of poverty, until 1850.” (Abrams, 1993, p. 1053)

The state of feeling to which Tennyson was most intensely drawn was a melancholic isolation.

Apart from the mood of utter despair, we find this poem musical, too, which is produced mainly by an application of refrain. Tennyson's use of refrain in this poem is brilliant. In the first six stanzas the alternation in the refrain of the words 'life,' 'night,' and 'day' not only gives variation but also work as a link to the preceding lines. In this connection, Hester Burton comments that

"The true magic lies in the subtle change of music in the last refrain with the introduction of 'very' in the first line and the harsh expletive 'God' in the last we leave Mariana to that final hard bitterness of unrequited love."(Burton, 1954, p. 42)

So, "Mariana”, too, shows lyrical qualities.

“Break, Break, Break”(1842) is one of the finest lyrics of Tennyson. It demonstrates the poet's intense mental pain that finds expression in a musical language. This lyric is yet another elegy over the premature death of his friend, Arthur Henry Hallam. The poet looks at waves breaking against the coast, at the fisherman's boy happily shouting with his sister at play, and at the majestic ship sailing to the harbour for rest, but all these leave the poet's heart very sorrowful and griefstricken. He is fully unable to express the thoughts and feelings which 
arise in him. The beauty and grace of the days when the poet's friend was alive will never come back:

But the tender grace of a day that is dead

Will never come back to me. (“Break, Break, Break”, 15-16, p. 1071)

Nonetheless, in this short poem, the poet's sad sensation fuses into melody, for he adopts different methods in order to produce mournful cadence. Here refrain, alliteration and onomatopoeia are used. The first line - "Break, break, break"- refrains at the top of the last stanza while the word 'break' bespeaks onomatopoetic effect. Indeed, here alliteration itself is onomatopoetic. Moreover, the recurrence of 's' (stones, sea, short, sister, stately, ships), and 'b' (break, boat, boy) sounds causes alliterative effect. Therefore, lyrical strain stands out as a conspicuous feature in this poem.

Next the reading of Arnold's poems will show how they exhibit a lyrical strain. In every lyric, Arnold instills his own sadness and dissatisfaction. He looked at the world around him, saw everywhere a ceaseless change taking place, and was sad. Unlike the buoyant confidence of Browning he felt only misgiving. The religious doubts that made Tennyson desolate set Arnold to musing cheerlessly on the meaning of life. This modern feeling of dissatisfaction and loss is expressed in his poems with a classic restraint. Emile Legouis and Louis Cazamian rightly observe that "the true note of Arnold's temperament is sadness: a pensive melancholy, essentially Romantic in origin, which gains sterner tones from the more definite anxieties of the century.”(Legouis \& Cazamian, 1996, p. 1189) With Arnold there is a feeling of wound, the loss of that cheerful temper which is so much unique to Clough and which emanates from his faith. The vague Christianity of Arnold, the moral pantheism to which all his philosophical reflection tends, seems to have left in his inner self an emptiness, a scar which is revealed only in his poetry. In "Dover Beach” (1867) this religious anguish is perceptible.

“Dover Beach”(1867), which is the summary statement of all lyrics of Arnold, concerns his poignant, personal sadness resulting from the loss of certitude in religion. Arnold often uses "the image of the ocean to symbolize the sadness. In "Dover Beach", he describes the 'melancholy long withdrawing roar' of the 'Sea of the Faith'."(Zeleny, 1988, p. 743) About the source of Arnold's mood of dejection, Leon Gottfried says: "Brought up in a Christian tradition in which joy and 
salvation were contingent upon certitude of faith, the loss of certitude meant equally the loss of joy"(Gottfried, 1963, p. 23). The world has no appeal to him:

For the world, which seems

To lie before us like a land of dreams,

So various, so beautiful, so new

Hath really neither joy, nor love, nor light,

Nor certitude, nor peace, nor help for pain;

(“Dover Beach”, 30-34, p. 1367)

Christianity embraces the whole of life with so much strength that when one ejects himself out of it, everything seems insipid. In this connection, Ernest Renan has expressed Arnold's forlornness:

"I was terribly lost. The universe produced upon me the impression of a cold and arid desert. For the moment that Christianity was not the truth, all the rest appeared to me indifferent, frivolous, barely worthy of interest." (Gottfried, 1963, p. 23)

Forlorn and deserted, Arnold "sees himself as a fish out of water as well.” (Gottfried, 1963, p. 23) From the above comment by Gottfried, it can easily be realised what the state of Arnold's mind is like. As to its music, "Dover Beach" is highly melodious. The following lines contain the sad music:

The sea of faith

Was once, too, at the full and round earth's shore

Lay like the folds of a bright girdle furl'd ;

But now I only hear its melancholy, long, withdrawing roar,

Retreating to the breath

Of the night-wind down the vast edges drear

And naked shingles of the world.

(“Dover Beach”, 21-28, p. 1367)

The rhythm of the stanza is noteworthy, especially for the recurrence which indicates the use of alliteration- of 'l' (lay, like, girdle, furl'd), 
and ' $r$ ' (withdrawing, roar, retreating, breath) sounds. In the above lines, allocation may also be attributed to the musical cadence. In the third line of the stanza, in order to enhance the musical effect Arnold has written 'girdle furl'd' instead of 'furl'd girdle' which is the normal arrangement of the phrase. Again, the sixth line shows the use of allocation, where the poet has composed 'edges drear' which should actually run as 'drear edges'. This reversal transforms the lyric into a melody.

Unlike Tennyson and Arnold, Rossetti's lyrics are usually born out of the sentiment of love. In his lyrics there exists a sharp sense of pathos, which is his own. In this regard, as Oswald Doughty maintains "nearly all the essential poetry Rossetti wrote is intensely personal, subjective in essence."(Scott \& Kilvert, 1982, p. 244)

In order to show lyrical properties in Rossetti, a brief but fine lyric, entitled "The Woodspurge" (1870) may be considered. It "was written at a time of tension when Rossetti's continual postponement of marriage to Elizabeth had alienated the lovers."(Scott \& Kilvert, 1982, p. 242) This alienation inflicts piercing grief upon the poet's mind. At the beginning of the lyric, we find the poet suffering from inertia. He is walking 'at the wind's will' and he sits down on the grass once the wind has dropped. His pang is comprehensible when the following lines are recited:

Between my knees my forehead was

My lips, drawn in, said not Alas!

My hair was over in the grass,

My naked ears heard the day pass.

("The Woodspurge", 5-8, p. 1467)

It may also be possible that his mental anguish arises out of the memory of "his wife, Elizabeth Siddal, whose suicide in 1862 haunted him with a sense of guilt for the rest of his life.”(Abrams, 1993, p. 1460) "The Woodspurge" is an outburst of the poet's growing sense of isolation. Here the personal, sad emotions are blended with the symphony of music. In this lyric, rhyme scheme (aaaa, $b b b b, \ldots . .$.$) ,$ alliteration and assonance largely contribute to its overall melodious effect. For instance, the following stanza showing Rossetti's dejection may be quoted: 
The wind flapped loose the wind was still,

Shaken out dead from tree and hill;

I had walked on at the wind's will

I sat now, for the wind was still.

(“The Woodspurge”, 1-4, p. 1467)

The repetition of 'l' produces alliterative effect; and the stressed vowel sound in 'wind,' 'still,' 'tree,' 'hill,' 'will,' introduces assonantal effect. All this creates rhythmic sound suiting to the poet's severe mental pain.

Victorian lyricism in general is steeped in sadness and melancholy and seeks the weak consolations of oblivion. The poems of Tennyson, Arnold and Rossetti show how the lyrical strain is articulated in Victorian poetry. Victorian poets deal with subjectivity as well as melody in their lyrics. Subjectivity results from personal sorrows, doubt and frustration, and melody arises out of certain literary devices like alliteration, onomatopoeia, assonance and refrain. Particularly some alliterative sounds produce a variety of tonal effects. Although they all brood on personal feelings, the sources of the feelings are divergent. In other words, the mode of their lyrical strains is different from one another. Tennyson's feeling of grief that springs out of Hallam's death turns to doubt, but eventually he resuscitates his faith. Arnold ponders over decaying faith in religion as well as the meaninglessness of this world. And utterly different, Rossetti's emotions emanate from the delay of his union with his beloved as well as from her suicidal death. Indeed, Victorian poetry is suffused with the lyrical strain.

\footnotetext{
${ }^{1}$ All the extracts of Victorian Poetry have been incorporated from: ABRAMS, M. H. (1993), The Norton Anthology of English Literature, Sixth Edition, Vol. 2, W.W. Norton \& Company, New York.
} 


\section{References:}

1. ABRAMS, M. H. (1993); A Glossary of Literary Terms, Prism Books Pvt. Ltd., Bangalore, India.

2. ABRAMS, M. H. (1993); The Norton Anthology of English Literature, Vol. 2, W.W. Norton \& Company, New York, PP. 1053-1467.

3. BURTON, HESTER (1954); Tennyson, Oxford University Press, PP. 11-43.

4. GOETZ, PHILIP W. (1986); The New Encyclopedia Britannica, Vol.7, Encyclopedia Britannica, Inc., Chicago.

5. GOTTFRIED, LEON (1963); Matthew Arnold and the Romantics, Rontledge \& Kegan Paul, London.

6. LEGOUIS, EMILE \& CAZAMIAN, LOUIS (1996); History of English Literature, Macmilan India Limited, New Delhi.

7. SCOTT IAN \& KILVERT (1982); British Writers, Vol. V, Charles Scribner's Sons, New York, PP. 242-244.

8. ZELENY, ROBERT O. (1988); The World Book Encyclopedia, World Book, Inc., A Scott Fetzer company, Chicago. 